Ein neuer Veränderlicher im Schwan.

BD. $+43^{\circ} 3268 \quad 9^{\mathrm{m}} \circ \mathrm{o} \quad 19^{\mathrm{k}} 26^{\mathrm{m}} 37^{\mathrm{s}}$. $\quad+43^{\circ} 19^{\prime} 5 \quad$ I 855.0 .

Bei den genauen Helligkeitsbestimmungen aller in den Grössenschätzungen unter sich oder gegen die BD.Grössen und andere Quellen stärker abweichenden Sterne meines AG.-Catalogs habe ich Nr. I3086 desselben als veränderlich erkannt. Der Stern ist bier in den BD.-Zonen beobachtet:

\begin{tabular}{|c|c|c|c|c|c|c|}
\hline 18 & & & Schönfeld & r klare Luft & & 9.0 \\
\hline 51 & 56 & Oct. 18 & $\gg$ & Neblige Luft & & 9. \\
\hline$. Z . \quad 275$ & 1858 & Sept. 23 & Krueger & Luft sehr gut, heller & Mondschein & y. \\
\hline
\end{tabular}

In den AG.-Zonen ist der Stern beobachtet :

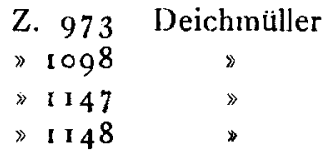

Hiernach habe ich seine Grösse im AG.-Catalog zu $8 \cdot 3$ angesetzt. Der Stern fehlt in Bessel's Zone 4851829 A ugust 27.

r 898 Oct. 2 fand ich den Stern am Schröder'schen Refractor nur mit den schwächsten BD.-Sternen vergleichbar, also über eine Grösse schwächer als zu den Zeiten meiner letzten drei Meridianbeobachtungen des Sterns, und ich war daher, da der Stern keine besondere Färbung aufweist, von seiner Veränderlichkeit überzeugt. Die seither von mir beobachteten Lichtstärken bestätigen diese Annahme, und zwar ist der Stern jetzt im aufsteigenden Aste der Lichtcurve.

Die Vergleichsterne sind $d=43^{\circ} 32669^{\mathrm{m}} \cdot 3 ; c=$ $43^{\circ} \cdot 3^{264} 9^{\mathrm{m}} \cdot 2 ; a=43^{\circ} \cdot 32579^{\mathrm{m}} \cdot \mathrm{\circ} ; b=43^{\circ} \cdot 3^{2} 5^{6} 8^{\mathrm{m}} \cdot 5$. Die Lichtstärken von $d$ und $c$ verhalten sich am Himmel umgekehrt wie in BD., $d$ ist der hellere, $c$ der schwächere. Für die Grössen nehme ich nach bisherigen Vergleichungen vorläufig folgende Stufenwerthe an:

$$
\begin{aligned}
& c=0 \\
& d=2.5 \\
& a=6.5 \\
& b=9.5
\end{aligned}
$$

Die Beobachtungen ergeben:

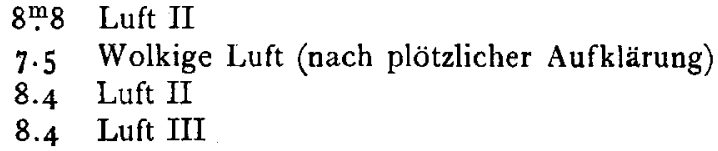

I 899 Jan. 2 I. Etwas streifige Luft,

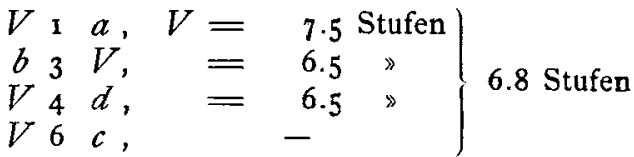

Der Stern hat hiernach seit Anfang October um $2 / 3$ Grössenclassen zugenommen, und er verdient jetzt thunlichst beobachtet zu werden, bevor er in ungünstigere Stellungen, näher am Horizonte, gelangt.

Bonn, 1899 Jan. 24.

Fr. Deichmüller.

\title{
Elements and ephemeris of comet 1898 VIII (Chase).
}

From my observations of Nov. 23, Dec. 7 and Dec. 16, 1898, I have computed the following elements of this comet. The first two observations were made with the $\mathrm{I} 2$ inch telescope and the third with the 36 inch refractor.

\section{Elements.}

$$
\left.\begin{array}{rl}
T & =189^{8} \text { Sept. } 20.15344 \text { Gr. M. } T . \\
\omega & =4^{\circ} 37^{\circ} 59^{\prime \prime} 9 \\
\delta & =955^{1} 35.9 \\
i & =223020.3
\end{array}\right\} \text { 1 } 8990
$$

The above elements give the following residuals for my recent observations with the 36 inch refractor $(O-C)$ :

$$
1899 \text { Jan. } 4 \Delta \alpha=+0.19, \Delta \delta=+2.2 ; \text { Jan. } 5 \Delta \alpha=+0.17, \Delta \delta=+1.5 \text {. }
$$

The smallness of these residuals would seem to indicate that the true orbit of this comet is sensibly parabolic and that there is no probability of its being identical with comet $1867 \mathrm{I}$, as has been suggested. 